\title{
Experiences of shame, guilty emotion, and socialization of Batak cultural values among Batak Toba older and younger generations
}

\author{
M. N. Erri Mutiha Hutapea ${ }^{1 *}$, Julia Suleeman $^{1 * *}$ \\ ${ }^{1 .}$ Faculty of Psychology, Universitas Indonesia, Depok Jawa Barat, Indonesia \\ *E-mail: errimutihahutapea@gmail.com \\ *E-mail: julia.suleeman@ui.ac.id
}

\begin{abstract}
This study aims to describe and identify shame and guilty emotions among older generation of Batak Toba people as compared to the younger generation. Fifty participants from each of the older generation and the younger generation were asked to complete Test of Self-Conscious Affect 3 (TOSCA-3). In addition, three older and three younger participants were individually interviewed to get a more complete picture on the socialization of Batak Toba cultural values and emotion. Results show that there are significant differences on shame emotion between older and younger generations $t(98)=5.104, p<.001$, but not on guilty emotion $t(98)=1.912$, $p>.001$. From the interviews it was clear that there are both similarities and differences between the two generations on the kinds of situation that bring shame emotion and the expression of it. For guilty emotion, there was a significant difference between older and younger generations were found between older and younger generations. Socialization for shame and guilty emotions for both generations came from families, schools, friends, and church teachings.
\end{abstract}

Keywords: Batak Toba, guilt, shame, socialization

\section{Introduction}

Indonesia is known as a country with a collectivist culture. Individuals in collectivist cultures usually behave based on other people's perception, tradition and upheld values (Shiraev \& Levy, 2010). That is why some studies showed that collectivists culture has a positive association with some moral emotions, such shame culture (reference) and guilt culture. Yet, presently many news covered by the media is filled with cases such as violence, corruption, fraud and many others. The news does not reflect behaviors based on other people's perception toward tradition or upheld values. Please find another samples. Built on those facts, it seems that shame and guilt culture is even getting away from collectivist culture. Present study seeks to examine those moral emotions in Indonesia contexts, particularly in Batak Toba.

According to Berten (2007), shame culture is a culture where "respect", "reputation", "good name", "status" and "prestige" are considered as important values. Bertens further stated that in shame culture the penalty for making a mistake comes from outside, which is based on what other individuals think or say. In contrast to shame culture, guilt culture is a culture where "sin" and "guilt" are highly regarded.

Beside of shame culture, collective cultures are also known having an association with guilt culture.

Shame and guilt have some similarities, among them, 1) they are categorized as moral emotion because of their role in developing moral behavior and preventing moral violation; 2) they are categorized as self-conscious emotion, where each of those emotions are involved in the evaluation process toward the self-standard as well behavior standards (Lewis, 1990 in Tangney \& Fischer, 1995); 3) they are emotions that usually appear as response toward failure or violation; 4) they usually happen within interpersonal context, and aside that, in situations that can bring up the emotions of shame and guilt.

In the emotion of shame, there is the desire to hide or escape, or to lash back. While in guilt emotion, there is the desire to admit fault, ask forgiveness or reparation (Tangney \& Fischer, 1995). Shame and guilt are important emotions, because both can be regarded in developing moral behavior and prevent moral violation. The emotions of shame and guilt can be perceived similarly or differently, because 
we often feel, analyze and have thoughts about those emotions from different perspectives. Culture forms the emotions differently because of different interpretations toward the situation (Shiraev \& Levy, 2010). While some other studies have showed that... (please summarize some previous findings on these emotions here), there are still lack of studies on this issue in Indonesia context.

Indonesia is culturally rich for it has many cultures and tribes. One of the main cultures is Batak.). Shame and guilt emotions can be identified in Batak tribes. In the Batak language, 'shame' is called "maila, while 'guilt' is still called 'salah' (guilt or wrong in Bahasa Indonesia) because there is no particular Batak word for the word 'guilt' Pakpahan (2006) stated that someone with maila, shows shame after doing a mistake. Maila does not only come from other people's opinions, but also because internal awareness for have violated some rules. The sense of shame is the opposite of life goals of Batak tribes, known as $3 \mathrm{H}$, namely Batak is known to have $3 \mathrm{H}$ life goals . It refers torespect (hasangapon), descendants (hagabeon), and wealth (hamoraon). Before specifically explained how shame emotion might contradict with Batak's life goals, below we summarized what are those life goals.

The three life goals of Batak people does not necessarily exclusive goals. Those three life goals can go together, for example someone possess respect for having children and wealth, or one can be wealthy because of having children and wealth. Aside the $3 \mathrm{H}$, the Batak people also have a philosophy of "Dalihan Na Tolu". Ihromi (in Vergouwen, 2004) stated that Dalihan Na Tolu is a framework that covers the familial relationships through blood and marriages. Dalihan Na Tolu can be understood as 'Tungku yang Tiga' (the Stoves that are Three) or Tungku nan Tiga. The three stoves that support the livelihood of the entire Batak Toba cultural system is the Hula-hula - Dongan Sabutuha - Boru (Harahap and Siahaan, 1987). Dalihan Na Tolu consists of somba marhula-hula (respect toward the wife's family),manat mardongan tubu (being careful to those of the same clan), as well elek marboru (being persuasive and loving when speaking toward the daughter or sister) (B. Hutapea, personal interview, 19 May 2015).

The life purpose and philosophy of the Batak people mentioned above is usually taught from one generation to the next. As stated by Harahap and Siahaan (1987) the cultural values that appear in the daily lives of the Batak Toba society, is inherited generationally from one generation to another through many ways. One way is by a traditional way of expression which consists of advice or persuasion (poda), old sayings (umpama), poetry verses (umpasa) which are often given in three important events in the life cycle, which is birth, marriage and death. Besides conserving the The socialization process of shame and guilt emotion among the old and young generation is done by the parents as well the church minister. The older generation mentioned the cultural elders and friends as other agents of socialization, while the younger generation mentioned the school. The socialization of shame and guilt emotion among older and younger generation is done by giving advice by parents through the religious teaching. Yet, the older generation mention the socialization of shame and guilt emotion is also received from advice (umpasa) that are usually obtained from someone older that is a guide of living for Batak people. This umpasa is usually given during cultural events such as weddings, funerals and others. The scope of the event usually involves large gathering, but can also be limited to just the immediate family (such as celebration for the child's baptism). The younger generation mentioned reading textbooks in school and catechism books in church are also ways to know something that can causes shame or know what would be wrong.ancestral teachings, the inheritance of these cultural values is expected to guide the next generation in reaching their life purposes which is the ideal standard of the Batak people $(3 \mathrm{H})$.

It is important to know how the ideal standard and the behavioral standards are something internalized in the individual. How does the individual arrive to the point that the individual realize that those are important to themselves and others? According to Barrett (in Tangney \& Fischer, 1995), those standards are formed in the individuals through their childhood interactions, with their parents and other loved ones. The child's dependency toward the individuals around him, especially the parents, have become their first and most important agents of socialization. Barett (in Tangney \& Fischer, 1995) described that such children-parents interaction plays a role in developing shame and guilt in the child.

Papalia and Feldman (2012) define socialization as a process of shaping habits, skills and values. Through this shaping process, individuals are more responsible and become productive community members. Being obedient toward the parents' 
wishes, is said to be the first step in achieving the social standard expected from the individual. A child that has internalized the standards socialized by the environment, is no longer expected to obey just to receive a reward, but to also use the social standard as his own personal standard. The socialization agents that act in the socialization process among them are, families, school, friends, mass media and the community. But changes from time to time, such as the current digital era, allowed a difference of socialization that is done in the past compared to the present. Seeing the Batak culture that is inherited generationally, this study focuses on the differences in the emotional experiences of shame and guilt, as well the differences of socialization that might exist between the older and younger generation of Batak Toba people.

\section{Methods}

Participant. In total, present study employed 100 participants. 50 participants were those aged 65 years old and above $((\mathrm{M}=69.96, \mathrm{SD}=\ldots) .32$ of them were women and 18 of them were men. The other 50 participants were younger generation,aged from 18 to 20 years old $(\mathrm{M}=18.14, \mathrm{SD}=\ldots$.$) . 31$ of them were women and $19 \mathrm{pf}$ them were men. They were borned and raised in North Sumatera, have parents from Batak Toba ethnicity, and has never lived in an urban area or big city. Three participants from older generations and three participants from young generations were randomly chosen for the interview..

Research Instrument. The research instrument is the Test of Self-Conscious Affect 3 (TOSCA-3), which was developed by Tangney, Dearing, Wagner and Gramzow (2000). TOSCA-3 is actually used to measure shame, guilt, externalization, detachment, alpha pride and pride in behavior. For the purpose of present study, only items examine shame and guilt were selected. The items were translated into Bahasa Indonesia. TOSCA-3 instrument consisted of situational scenarios encountered in the daily life (see Table 1). The scenario formats were made based on the discovery that people have difficulty differentiating between the concepts of shame and guilt compared to situations that causes shame and guilt emotions (Lindsay-Hartz, 1984; in Woien, Ernst and Patock-Peckham, Nagoshi, 2002). The TOSCA-3 was administered with paper and pencil test to the participants.

Previously, a study by Barlian (2013) has made made elicitations to obtain a description of situations that causes shame and guilt emotion in
Indonesia. Elicitation was made by conducting a Focus Group Discussion with two groups that represent the older and younger generation.

The result of reliability testing using alpha's Cronbach indicated a good reliability coefficient, which 0.798 for item reliability measure shame emotio and 0.822 for the reliability of items measuring guilt emotion.

Data Analysis. For the quantitative study,this study used descriptive statistics and Independent Sample t-test. The qualitative method used in this study are personal interviews and participative observation.

\section{Results}

a. Mean Comparison of Shame and Guilt among older and younger generations

Table 1

Differences between older and younger generations on shame and guilt

\begin{tabular}{lccc}
\hline \multicolumn{1}{c}{ Shame } & Mean $(S D)$ & $t$ & $p$ \\
\hline $\begin{array}{l}\text { Older generation } \\
\text { Younger generation }\end{array}$ & $38.92(8.303)$ & 5.104 & $<.001$ \\
\hline \multicolumn{1}{c}{ Guilt } & Mean (SD) & $t$ & $p$ \\
\hline $\begin{array}{l}\text { Older generation } \\
\text { Younger generation }\end{array}$ & $54.62(9.435)$ & 1.912 & .059 \\
\hline
\end{tabular}

As we can see from the table above, older generation has higher scores on shame $(M=38.92)$ and guilt emotions $(M=54.62)$ as compared to younger generation $(M=29.54, M=51.54)$. Independent sample $\mathrm{t}$ test revealed that there was a significant differences of shame in older than younger generation $t(98)=5.104, p<.001$. It was also found that there was a marginally significant differences of guilt in older than younger $t(98)=$ $1.912, p=.059$.

\section{b. Results from personal interviews.}

There are similarities in situations that trigger shame and guilt among older and younger generations. The difference is that older generation feel shame in front of God while younger generation when they become center of attention and how they dress as causes of feeling shame. In expressing shame and guilt, older generation also include praying while younger generation tries to not show the shame. 
Table 2

Differences between older and younger generations on shame and guilt

\begin{tabular}{|c|c|}
\hline Older Generation & Younger Generation \\
\hline \multicolumn{2}{|c|}{ Situations that trigger shame } \\
\hline $\begin{array}{l}\text { Physical and financial } \\
\text { shortness; wrong behavior } \\
\text { (not as expected by the } \\
\text { other people); family } \\
\text { dispute known by other } \\
\text { people; shame in front of } \\
\text { God; not respecting older } \\
\text { or more respected people; } \\
\text { not being good children or } \\
\text { parents. }\end{array}$ & $\begin{array}{l}\text { When avoided by other } \\
\text { people; felt cornered; } \\
\text { being a center of } \\
\text { attention; other people } \\
\text { know the personal or } \\
\text { family secrets, improper } \\
\text { dressing. }\end{array}$ \\
\hline \multicolumn{2}{|c|}{ Situations that trigger guilty } \\
\hline $\begin{array}{l}\text { Behaviors that hurt other } \\
\text { people; not respecting } \\
\text { family elders; not being } \\
\text { good children or parents. }\end{array}$ & $\begin{array}{l}\text { Breaking promises; } \\
\text { fighting with friends; } \\
\text { making someone hated } \\
\text { by other people. }\end{array}$ \\
\hline
\end{tabular}

\section{Table 3}

Differences between older and younger generations on shame and guilt

\begin{tabular}{|c|c|}
\hline \multicolumn{2}{|c|}{ Expression for shame } \\
\hline $\begin{array}{l}\text { Withdrawing from social } \\
\text { life (by not attending } \\
\text { cultural rites); stay calm } \\
\text { and brave; asking for } \\
\text { forgiveness; reflecting; } \\
\text { praying. }\end{array}$ & $\begin{array}{l}\text { Trying to cover the } \\
\text { shame emotion; stay } \\
\text { calm and quiet; bowing } \\
\text { head; walking fast, } \\
\text { avoiding other people's } \\
\text { look. }\end{array}$ \\
\hline \multicolumn{2}{|c|}{ Expression for guilty } \\
\hline $\begin{array}{l}\text { Praying; getting closer to } \\
\text { the people being hurt; } \\
\text { asking for forgiveness; } \\
\text { stay quiet to avoid things } \\
\text { getting worse. }\end{array}$ & $\begin{array}{l}\text { Asking for forgiveness; } \\
\text { getting closer to people } \\
\text { being hurt. }\end{array}$ \\
\hline
\end{tabular}

Table 3 shows how older and younger generations differ in their socialization process of cultural values.

The socialization process of shame and guilt emotion among the old and young generation is done by the parents as well the church minister. The older generation mentioned the cultural elders and friends as other agents of socialization, while the younger generation mentioned the school. The socialization of shame and guilt emotion among older and younger generation is done by giving advice by parents through the religious teaching. Yet, the older generation mention the socialization of shame and guilt emotion is also received from advice (umpasa) that are usually obtained from someone older that is a guide of living for Batak people. This umpasa is usually given during cultural events such as weddings, funerals and others. The scope of the event usually involves large gathering, but can also be limited to just the immediate family (such as celebration for the child's baptism). The younger generation mentioned reading textbooks in school and catechism books in church are also ways to know something that can causes shame or know what would be wrong.

\section{Table 4}

Differences of socialization process between older and younger generation

\begin{tabular}{|c|c|}
\hline Older Generation & Younger Generation \\
\hline \multicolumn{2}{|c|}{ Social Agent } \\
\hline $\begin{array}{l}\text { Family (parents, older } \\
\text { siblings, extended family } \\
\text { members), culture elders, } \\
\text { church minister, friends }\end{array}$ & $\begin{array}{l}\text { Parents, church minister, } \\
\text { school }\end{array}$ \\
\hline \multicolumn{2}{|c|}{ When started receiving socialization } \\
\hline $\begin{array}{l}\text { Since young attended } \\
\text { classes at church }\end{array}$ & $\begin{array}{l}\text { Since first grade attended } \\
\text { class at church }\end{array}$ \\
\hline \multicolumn{2}{|c|}{ Socialization method } \\
\hline $\begin{array}{l}\text { Were given umpasa } \\
\text { (advice) and umpama } \\
\text { (proverbs) at cultural rites, } \\
\text { or told family members, } \\
\text { church elders, based on } \\
\text { Bible }\end{array}$ & $\begin{array}{l}\text { Were told by parents, or } \\
\text { when reading school text } \\
\text { books, or at church by } \\
\text { church elders based on the } \\
\text { Bible }\end{array}$ \\
\hline \multicolumn{2}{|c|}{ Contents of socialization } \\
\hline $\begin{array}{l}\text { Parent's expectation, what } \\
\text { is regarded as Batak } \\
\text { Tobanese ideals, what are } \\
\text { right and wrong }\end{array}$ & $\begin{array}{l}\text { Parent's expectation, } \\
\text { behavioral standards, what } \\
\text { are right and wrong }\end{array}$ \\
\hline \multicolumn{2}{|c|}{ Cultural values } \\
\hline $\begin{array}{l}\text { Learning about umpasa } \\
\text { from elders, able to } \\
\text { explain Batak Toba values } \\
\text { (hamoraon, hagabeon, } \\
\text { hasangapon, etc), able to } \\
\text { explain about Batak Toba } \\
\text { family system (Dalihan } \\
\text { Na Tolu) }\end{array}$ & $\begin{array}{l}\text { Knowing (but not deep } \\
\text { enough) about Batak Toba } \\
\text { cultural values. }\end{array}$ \\
\hline
\end{tabular}

Shame and guilt emotions are socialized by parents in order to develop sense of ideal standard of Batakneese behavior and to be able to differentiate what is right and wrong. The older generation describe the link between hamoraon, hagabeon, hasangapon, and dalihan na tolu with the emotions of shame and guilt. Meanwhile, the younger generation cannot explain those Batak cultural values even though they know what they are called. 


\section{Discussion \& Conclusion}

Discussion. Significant differences between the shame emotion between the older and younger generation might be attributed to different values held by older generation. Lifespan and life experience allow the older generation to be able to convey values that are taught through many ways, thus these values are more internalized.

There is no significant difference between guilt emotion among older and younger generation. This is line with Silfver et al.'s study, (2008), which showed that guilt-proneness is positively correlated with values such as tradition and conformity. Thus, it can be said that the more an individual respect and commits toward the cultural traditions and religious teachings, the higher is the individual's guiltproneness. Based on observations, it is seen that both generations respect cultural rites and religious teachings. Even though, the older generation have a more understanding toward the rules of the performed cultural rites (such as weddings, funerals, baptism celebrations), the younger generation appears to have a role according to their position in the performed cultural rites. The younger generation appears to be willing to listen and follow the instructions given by the older generation when the cultural rite is being performed. According to the explanation of one younger generation participants being interviewed, they are willing to learn about the traditions of their customs because one day they will replace the older generation.

In the older generation, situations that bring up shame emotion are those that involve negative perception toward one's self (physically and materially), because they do not feel the same as the other individuals around them. Similarly, in the younger generation, shame emotion can appear in situations such as experiencing wardrobe malfunction, and other situations that make the individual feels avoided, cornered or being the center of attention. These situations can be described as one of the elements of shame as described by Lynd (1958, in Baldwin \& Ewald, 2006), which are incongruity and inappropriateness. In incongruities situation, there are differences between the individual's self and social situation. That individual is regarded as not behaving according to the expectation. That individual experiences loneliness and feel out of place. As by Tangney and Fischer (1995), when experiencing shame, the individual evaluate himself failing to fulfill the standards of his social environment.
Other situation that causes shame emotion in older generations is fighting with spouse that might be heard by the neighbors. The shame emotion that appears without the presence of other individuals is in line with what Tangney (2003) described, that shame emotion can appear without the presence of others, but appears in the thoughts of how other people perceive one's self. Other older generation member said, even if the neighbor did not hear the domestic fight, they will still feel shameful toward God. The older generation will also feel shameful if they do not respect their relatives, who is worthy of respect, because they have shame themselves by not being familiar with custom.

One expression of the same emotion displayed by the younger generation is by limiting or withdrawing one's self from his social life, while the younger generation show this by walking with the head down, walking in a quicker face and to avoid seeing other people directly. This matches what Tangney and Fischer (1995) stated that shame emotion involves the tendency to take actions such as hiding one's self, such as looking elsewhere or try to cover one's face with the hand.

Guilt emotions appear among older generation and younger generation in situations where one's action involves harm or disadvantage other individuals. The individuals realizes that their action has physically or emotionally hurt the other individual, and one way to not worsen the situation is by being silent, ask forgiveness, and approached the hurt party. In line with what Tangney and Fischer (1995) stated, that in guilt emotion one evaluates one's self as being responsible for the mistake that was done. In guilt emotion, Lewis (2008) stated that the action that has or has not been done has become the evaluation object.

When individuals in this study experience shame emotion, there is the desire to make reparations and ask forgiveness, approach and settle down so the situation does not worsen. This is in line as what Tangney and Fischer (1995) described whereas action tendencies of guilt emotion among them is the tendency to make reparations, fix the situation, ask forgiveness, confess, or seek absolution.

The socialization of shame and guilt emotion in the older and younger generation is obtained since childhood by a parent. According Gelles and Levine (1999), this is the primary agent of socialization for the following years. Additionally, the individual's 
socialization agents will increase following the individual's growth.

There are differences in knowledge between the older and younger generation regarding the Batak cultural value in teaching shame and guilt. The older generation mention hagabeon (descedents), hasangsapon (respect) and hamoroan (wealth) as the aspiration of everyone in the Batak tribe. Having descendants is important for Batak, either son or daughter are both regarded important, yet according to the older generation narration, a Batak hopes to have a son to continue the family name. Obtaining respect and being well regarded by society, and having wealth (both materially or non-materially) is also the aspiration of the Batak tribe. Shame and guilt emotion appear when the individual feels unable to achieve one or all of those expectations. Even if an individual has a respected family and obtain material wealth, if he does not have any descendants the individual will still receive comments like, "but he doesn't have any children.Simandjuntak (2002, in Ediningtyas, 2004) stated that hagabeon, hasangapon, hamoraon is a unity. Wealth is imperfect without descendants. Wealth can allow a Batak to successfully raise their children, gain respect from the community and set a good example.

Shame and guilt emotion also appear when the older generation feels unable to be a good child or parent. This circumstance, according to the older generation, can decrease others respect (hasangapon) toward themselves and their family. Shame and guilt emotion also appear in the familial relationships Dalihan Na Tolu), if someone does not respect their relative who is in the position as the hula-hula in a cultural rite.

By frequently listening to the advice through umpasa, which is usually done during cultural rites, allow the older generation to know and mention examples of umpasa that are given down generationally. "Muba dolok, muba duhutnya, muba huta, muba uhumna" has a meaning that in every area there are different customs so the Batak people are expected to realize those differences and adapt to them. "Jujur mula ni bada, bolus mula ni dame" means that being forgiving and doing so willingly will create peace. According to the older generation, there are many other umpasa that can be use for daily guide among the community of Batak people. Understanding upon cultural values and advises in the umpasa rituals, are not possessed by the younger generation of this study, even though they are familiar or have heard of this cultural value. As age increases, the younger generation might be more involved in the cultural rites and increase their understanding of the cultural values of the Batak tribe. Further studies can perhaps examine the socialization process of shame emotion and guilt emotion of one Batak tribe toward the next generation in the North Sumatera province.

This study has some limitations in the language usage in the instrument which was hard to understood by some of the older generation who mostly did not obtain higher education. Moreover, the research assistants were not necessarily able to accurately translate the questions into the Batak language. Future research should consider to use language in relatable context with the participants' daily life, and also to do longer and more systematic observation method to enriches the research.

Conclusions. The results of this study indicate that there are significant differences of shame emotion between the older and younger generation of Batak people. However, there was no significant differences in guilt emotion. This is explained by the wisdom of the older generation that make cultural values of shame and guilt emotion being more internalized. Meanwhile, the insignificant difference of guilt emotion could be explained by the notion that the more individuals honor and commit toward their cultural traditions and religious teachings, the higher their guilt-proneness. This research also discovered differences of knowledge regarding the Batak cultural values that teaches shame and guilt emotion. The older generation have frequently been exposed to cultural rites and advices of the umpasa, allowing them to be more knowledgeable and understanding of the cultural link between the cultural values with the shame and guilt emotion. While younger generations........ Possibly it is because Batak parents in present days are no longer possing a deep concern on cultural values. To address this issue, it is important for social agents such as parents, families and the community to continues value socialization, so the younger generation could continue to carry on the traditions containing ancestral values.

\section{References}

Aiken, L. (1995). Aging: An introduction to gerontology. New York: Sage.

Ausubel, D. (1955). Relationships between shame and guilt in the socializing process. Psychological Review, 62(5), 378-390. 
Baldwin, K., Baldwin, J., Ewald, T. (2006). The relationship among shame, guilt, and selfefficacy. American Journal of Psychotherapy, 60(1), 1.

Barlian, I. Y., (2013). Perbedaan emosi malu dan emosi bersalah pada generasi tua dan generasi muda. Skripsi. Depok: Fakultas Psikologi Universitas Indonesia.

Bertens, K. (2007). Etika. Jakarta: Gramedia Pustaka Utama.

Gelles, R., Levine, A. (1999). Sociology: An introduction (6th ed). United States of America: McGraw-Hill College.

Harahap, B., Siahaan, H. (1987). Orientasi nilainilai budaya Batak: Suatu pendekatan terhadap perilaku Batak Toba dan Angkola Mandailing. Jakarta: Sanggar Willem Iskander.

Lewis, M., Haviland-Jones, J., Barrett, L. (Eds.). (2008). Handbook of Emotions (3rd ed.). New York: The Guilford Press.

Pakpahan, B.J., (2016). Shameless and guiltless: The role of two emotions in the context of the absence of God in public practice in the Indonesian context. Brill Exchange, 45, 1-20.

Papalia, D.E., Feldman, R.D. (2012). Experience Human Development (12 ${ }^{\text {th }}$ Ed). New York: McGraw-Hill

Plutchik, R. (1994). The psychology and biology of emotion. New York: Harper Collins College Publishers.

Sianipar, S. H. W. (1991). Tuho Parngoluaon Dalihan Na Tolu: Sistem Bermasyarakat Bangso Batak. Medan, Indonesia: Pustaka Gama

Shiraev, E., Levy, D. (2010). Cross-cultural psychology: Critical thinking and contemporary applications $\left(4^{\text {th }} \mathrm{ed}\right)$. Boston: Allyn \& Bacon.

Silfver, M., Helkama, K., Lonnqvist, J., Verkasalo, M. (2008). The relation between value priorities and proneness to guilt, shame, and empathy. Motivational Emotion, 32, 69-80.

Tangney, J.P., Fischer, K.W. (Eds). (1995). Selfconscious emotions: The psychology of shame, guilt, embarrassment, and pride. New York: Guilford.

Tangney, J.P., Dearing, R.L., Wagner, P.E., Gramzow, R.H. (2000). The test of selfconscious affect - 3 (TOSCA-3). George Mason University, Fairfax, VA.

Vergouwen, J. (2004). Masyarakat dan hukum adat Batak Toba (Fuad Mustafid, Trans.).

Yogyakarta: LKiS Pelangi Aksara. (Karya asli diterbitkan tahun 1986).
Woien, S., Ernst, H., Patock-Peckham, J., Nagoshi, C. (2002). Validation of the TOSCA to measure shame and guilt. Personality and Individual Differences, 35(3), 313-326 


\section{Appendix}

Table 1.

Example of situational scenarios in TOSCA-3 in Bahasa Indonesia

Anda memiliki janji bertemu dengan teman Anda. Pada pukul 10 malam, Anda menyadari bahwa Anda lupa memenuhi janji tersebut. Anda akan...

\begin{tabular}{|c|c|c|c|c|c|c|}
\hline No & Reaksi & TS & KS & AS & $\mathbf{S}$ & SS \\
\hline 1. & $\begin{array}{l}\text { Berpikir: } \\
\text { "Saya tidak } \\
\text { peduli } \\
\text { dengan } \\
\text { orang lain" }\end{array}$ & & & & & \\
\hline 2. & $\begin{array}{l}\text { Berpikir } \\
\text { bahwa Anda } \\
\text { harus } \\
\text { menebus } \\
\text { kesalahan } \\
\text { Anda } \\
\text { secepatnya }\end{array}$ & & & & & \\
\hline
\end{tabular}

Saat sedang bermain basket, bola yang Anda lempar mengenai wajah teman Anda. Ia merasa kesakitan. Anda akan...

\begin{tabular}{|c|c|c|c|c|c|c|}
\hline $\begin{array}{l}\text { No } \\
\end{array}$ & Reaksi & TS & KS & AS & $\mathbf{S}$ & SS \\
\hline 3. & $\begin{array}{l}\text { Berpikir : } \\
\text { "Melempar } \\
\text { bola dengan } \\
\text { baik saja } \\
\text { saya tidak } \\
\text { bisa" }\end{array}$ & & & & & \\
\hline 4. & $\begin{array}{l}\text { Berlatih } \\
\text { lebih keras } \\
\text { agar dapat } \\
\text { melempar } \\
\text { bola dengan } \\
\text { lebih baik }\end{array}$ & & & & & \\
\hline
\end{tabular}

